\title{
Effects of intraperitoneal administration of simvastatin on collagen deposition, inflammation level and wound tension in an experimental incisional wound model
}

\section{Deneysel bir insizyonel yara modelinde intraperitoneal simvastatin uygulamasının kollajen birikimi, inflamasyon seviyesi ve yara gerilimi üzerine etkinliği}

\author{
Ömer Arda Çetinkaya ${ }^{1}$, Süleyman Utku Çelik ${ }^{1,2}$, Nesrin Hasırcı ${ }^{3}$, Mehmet Gürel ${ }^{1}$ \\ ${ }^{1}$ Ankara Üniversitesi Tıp Fakültesi, Genel Cerrahi Anabilim Dalı, Ankara, Türkiye \\ ${ }^{2}$ Gülhane Eğitim ve Araştırma Hastanesi, Genel Cerrahi Kliniği, Ankara, Türkiye \\ ${ }^{3}$ Orta Doğu Teknik Üniversitesi, Fen Bilimleri Enstitüsü, Biyoteknoloji Anabilim Dalı, Ankara, Türkiye
}

\section{ÖZET}

GÍRŞ ve AMAÇ: Yara iyileşmesi tüm cerrahi işlemlerin önemli bir bileşenidir. Bu çalışmada, deneysel bir yara iyileşme modelinde intraperitoneal simvastatin uygulanmasının kollajen birikimi, inflamasyon seviyesi ve yara gerilimi üzerindeki etkilerini araştırmayı amaçladık.

YÖNTEM ve GEREÇLER: Çalışma üç gruba ayrılmış toplam 36 rat üzerinde gerçekleştirildi. Karın duvarı orta hat kesisinin primer onarımı yara iyileşme modeli olarak belirlendi. Grup 1'e yüksek doz $(5 \mathrm{mg} / \mathrm{kg} / \mathrm{gün})$ simvastatin, grup 2'ye düşük doz (1 mg/kg/gün) simvastatin, grup 3'e ise plasebo solüsyon preoperatif 14 gün boyunca intraperitoneal olarak uyguland. Ratlar yara gerilme kuvveti, kollajen birikimi ve inflamasyon skorları açısından karşılaştırıldı.

BULGULAR: Yüksek doz simvastatin grubundaki ortalama yara gerilme kuvveti, diğer ratlarınkinden düşük bulunmasına rağmen; gruplar arasında anlamlı bir fark saptanmadı $(\mathrm{p}=0,058)$. Tip I ve tip III kollajen seviyesi açısından gruplar arasında istatistiksel olarak anlamlı farklılık olduğu görüldü (sırasıyla; $p=0,011$ ve $p=0,002$ ). Çoklu karşılaştırma için yapılan post-hoc testleri sonucunda tip I kollajen seviyesi yüksek doz simvastatin grubunda kontrol grubuna göre anlamlı oranda yüksek bulunurken $\left(2,18 \pm 0,75^{\prime}\right.$ e karşı $\left.1,25 \pm 0,45 ; p=0,006\right)$; tip III kollajen seviyesi hem yüksek doz hem de düşük doz simvastatin grubunda kontrol grubuna göre istatistiksel olarak anlamlı şekilde daha yüksek bulundu (sırasıyla; 2,27 $\pm 0,78$ 'e karşı1 1,16 $\pm 0,38, p=0,002$ ve $1,90 \pm 0,70$ 'e karşı $1,16 \pm 0,38, p=0,015)$. Ancak inflamasyon skorları gruplar arasında anlamlı farklılık göstermedi $(p=0,186)$. TARTIŞMA ve SONUÇ: Her ne kadar yüksek doz simvastatin, tip I ve tip III kollajen seviyelerini anlamlı derecede arttırmış olsa da üç grup arasında yara gerilme kuvveti ve inflamasyon skoru açısından anlamlı farklılık olmadığı görüldü.

Anahtar kelimeler: Deneysel model, gerilme direnci, inflamasyon, kollajen, simvastatin, yara iyileşmesi

\begin{abstract}
INTRODUCTION: Wound healing is an important component of all surgical operations. In this study, we aimed to investigate the effects of intraperitoneal administration of simvastatin on collagen deposition, inflammation level, and wound tension in an experimental wound healing model.

METHODS: The study was carried out on 36 rats, divided into three groups. The primary repair of abdominal wall midline incision was determined as a wound-healing model. High-dose simvastatin $(5 \mathrm{mg} / \mathrm{kg} / \mathrm{day})$ was administered intraperitoneally for 14 days preoperatively in group 1 , low-dose of simvastatin $(1 \mathrm{mg} / \mathrm{kg} / \mathrm{day}) \mathrm{was}$ administered in group 2 rats, and the placebo solution was given to group 3 . Rats were compared in terms of tensile strength, level of collagen, and inflammation scores.

RESULTS: Although tensile strength of rats in group 1 was lower than those in other groups, this difference was not significant $(\mathrm{p}=0.058)$. Type I and type III collagen level were significantly different between groups $(\mathrm{p}=$ 0.011 and $\mathrm{p}=0.002$; respectively). The post-hoc test revealed that group 1 rats had significantly higher type I collagen level than those of group 3 rats $(2.18 \pm 0.75$ vs. $1.25 \pm 0.45 ; \mathrm{p}=0.006)$. The type III collagen in group 1 and group 2 were also significantly higher than that in group $3(2.27 \pm 0.78$ vs. $1.16 \pm 0.38, \mathrm{p}=0.002 ; 1.90 \pm 0.70$ vs. $1.16 \pm 0.38 ; \mathrm{p}=0.015)$. However, inflammation scores were not different between the groups $(\mathrm{p}=0.186)$.
\end{abstract}


DISCUSSION and CONCLUSION: Although high-dose simvastatin significantly increased type I and type III collagen levels; tensile strength and inflammation score among the three groups of rats were not significantly different.

Keywords: Collagen, experimental model, inflammation, simvastatin, tensile strength, wound healing

\section{INTRODUCTION}

A wound is the disruption of anatomic and functional integrity of the tissues which constitute the skin and mucosa (1). Wound healing is a complex and dynamic process that involves several physiologic mechanisms including inflammation, cell migration, angiogenesis, temporary matrix synthesis, collagen deposition, and reepithelization, respectively and occurs with the coordinated interaction of inflammatory cells, biochemical mediators, extracellular molecules, and cell groups $(1,2)$. A failure in this process results in a delay in skin wound closure and healing. Inflammation is an important cause of delayed wound healing due to proteolysis, oxidative stress, and accumulation of toxic substances that occur during inflammation. Moreover, the infection has a detrimental impact on the wound healing process by preventing angiogenesis and vascularization (3).

Wound healing defects are one of the important problems of the surgery and often occur as a result of a failure emerging in the normal stages of the healing $(1,4)$. Non-healing wounds affect about 3-6 million people in the United States each year. Besides, worldwide 2$5 \%$ of patients with wound infection undergo surgical procedures each year (3). Complications of wound healing also lead to impaired skin integrity and wound dehiscence, resulting in increased hospitalizations and added healthcare expenses (5). Additional pathological features such as diabetes and increased pressure on the wound may have a negative effect on the wound healing process. Therefore, there has been a growing interest in experimental or non-clinical studies that can accurately accelerate wound healing, prevent wound infection, and provide the ideal scar formation for evaluating new topical and systemic treatment modalities $(3,4,6,7)$.

3-hydroxy-3-metilglutarile coenzyme A (HMG-CoA) reductase inhibitors (statins) used in the treatment of dyslipidemia traditionally have also wide-spectrum pleiotropic effects. These effects of statins include nitric oxide production, antioxidative, stability in atherosclerotic plaques, cell proliferation and migration, immunomodulatory, anti-inflammatory, antibacterial activities, and improvement of microvascular function and reperfusion as well as reducing the levels of serum cholesterol (3,7-10). HMG-CoA reductase inhibition reduces the matrix metalloproteinase enzyme expression and prevents collagen destruction (11). Some recent animal models also suggested that statins have positive effects on the wound healing process (3,5,7-9).

In this study, we aimed to investigate the effects of intraperitoneal administration of simvastatin on collagen deposition, inflammation level, and tensile strength of the wound in a rat incisional wound model.

\section{METHODS}

\section{Animals, experimental protocol, and study design}

The study was approved by the Animal Experiments Ethics Committee in Ankara University (approval number: 2010-60-309) in concordance with the Guide for the Care and Use of Laboratory Animals. 36 male Wistar Albino rats whose body weights vary between 240-260 grams were used in the study. Rats were held in bright/dark periods for 12 hours and $22-24^{\circ} \mathrm{C}$ room temperature during the study. Standard rat feed and drinking water were used in the nutrition of rats. Surgical procedure, anesthesia delivery, and animal care methods were performed according to the regulation of Animal Experiments Ethics Committee.

\section{Solutions prepared}

After $400 \mathrm{mg}$ Simvastatin (Zocor ${ }^{\circledR}$, Merck Sharp \& Dohme, Istanbul, Turkey) was powdered, dissolved $10 \mathrm{~mL}$ of $96 \%$ ethanol and $15 \mathrm{~mL}$ of $1 \%$ sodium hydroxide $(\mathrm{NaOH})$ was added for preparing the solution of simvastatin. The solution was waited in the $50^{\circ} \mathrm{C}$ of water bath for 2 hours and buffered with hydrochloric 
acid $(\mathrm{HCl})$ in such way its $\mathrm{pH}$ value would be 7.2. Finally, $75 \mathrm{~mL}$ of distilled water was added, and the solution was completed to $100 \mathrm{~mL}$. Then, $1.25 \mathrm{mg} / \mathrm{mL}$ and $0.25 \mathrm{mg} / \mathrm{mL}$ of solutions were prepared according to the formula [(required concentration $\mathrm{x}$ required volume) / stock solution concentration]. As placebo, a solution that contains $10 \mathrm{~mL} 96 \%$ ethanol and $15 \mathrm{~mL} 1 \% \mathrm{NaOH}$, does not contain simvastatin, was buffered with $\mathrm{HCI}$ for making its $\mathrm{pH}$ value 7.2 and finally completed to $100 \mathrm{~mL}$ by using $75 \mathrm{~mL}$ of distilled water, was prepared.

\section{Working groups}

Rats were randomly divided into three groups in such way there would be 12 rats in each group and the solutions were intraperitoneally administered to every rat for 14 days: Group 1 , $1 \mathrm{~mL}$ of solution containing $5 \mathrm{mg} / \mathrm{kg} /$ day simvastatin; group 2, $1 \mathrm{~mL}$ of solution containing $1 \mathrm{mg} / \mathrm{kg} /$ day simvastatin; and group $3,1 \mathrm{~mL}$ of solution not containing simvastatin (as a placebo solution).

\section{Anesthesia process and surgical procedure}

All rats were anesthetized by intramuscular injection of $30 \mathrm{mg} / \mathrm{kg}$ ketamine (Ketalar ${ }^{\circledR}$, Pfizer Ltd., Sandwich, UK) and $20 \mathrm{mg} / \mathrm{kg}$ thiopental (Pental Sodyum ${ }^{\circledR}$, Ulagay Ltd., Turkey). A heating lamp was used to ensure an adequate body temperature for the animals. After the abdominal front wall was trimmed, antisepsis was administered with $1 \%$ of povidone-iodine and then, laparotomy extending from xiphoid protrusion to the pubic bone was performed. Abdominal front walls and skins were repaired with 3-0 polypropylene suture in a continuous method. Standard rat diet and water ad libitum were given for all subjects after the operation.

\section{Follow-up}

Rats were allowed to the wound healing process without making any procedure for 14 days. At the end of this period, two specimens $(3 \times 1 \mathrm{~cm}$ and $1 \times 1 \mathrm{~cm}$ ) taken from abdominal front walls of the rats were subjected to tensile strength measurement and pathological examination. Tissue samples taken for pathology were fixed in $10 \%$ buffered formalin and the samples taken for the measurement of tensile strength were kept in saline solution. After the study, all rats were sacrificed.

\section{Measurements and pathological evaluation}

The tensile strength of the wounds was measured using the Lloyd Instruments testing machine (LRX5K ${ }^{\circledR}$, Lloyd Instruments Limited, Hampshire, UK) at a loading rate of 10 $\mathrm{mm} / \mathrm{min}$, rupture points were calculated, and force-elongation curve was determined.

$5 \mu \mathrm{m}$ of sections that were taken from the $1 \times 1 \mathrm{~cm}$ tissues were examined by staining with hematoxylin and eosin (H\&E) (Figure 1). The existence of inflammation in sections was evaluated with a semi-quantitative scoring system (range of $0-3$ ) (Table 1). Immunohistochemical staining was made on the sections taken by using Ventana automatic immune staining machinery (Bench Mark XT ${ }^{\circledR}$, Automated Slide Preparation System, Ventana Medical Systems Inc, Arizona, USA). Type I (Abcam, 1:500 dilution) and type III collagen (Innovex, 1:20 dilution) staining was studied with this method (Figure 2). Immunohistochemical staining was scored between 0 and 3 according to a histologic scoring system described by Abramov et al. (12).

\section{Statistical analysis}

Data were expressed as mean \pm standard deviation. The Kruskal-Wallis test was used to compare tensile strength, type I collagen level, type III collagen level, and inflammatory cell infiltration score. If a significant difference was found, a pair of variables in the three groups was assessed with the Mann-Whitney $U$ test. Because three tests were performed, Bonferroni adjustment was applied with the alpha level set at $\mathrm{p}=0.0167$ (i.e., $0.05 / 3$ ). For all analyses, a $P$ value of $<.05$ was considered to indicate statistical significance. All analyses were performed using Statistical Package for the Social Sciences version 16.0 for Windows (SPSS, Chicago, IL).

\section{RESULTS}

During the follow-up period, one rat in group 1 and one rat in group 3 died. Other rats survived with no clinical signs of infection or fever during the study. Besides, no side effects or adverse reactions occurred in any rat. 


\section{Tensile strength}

The tensile strength of tissues was calculated as $8.15 \pm 3.14 \mathrm{~N}$ for group $1 ; 10.59 \pm 1.87 \mathrm{~N}$ for group 2 and $9.47 \pm 1.32 \mathrm{~N}$ for group 3 .

There were no differences between groups regarding the tensile strength $(\mathrm{p}=$ 0.058). Although the tensile strength of rats in the first group was lower than those in other groups, this difference was not significant (Table 2). Force-elongation graphic of tissue samples subjected to mechanical tensile tests at $10 \mathrm{~mm} / \mathrm{min}$ was shown in Figure 3.

\section{Inflammation scores}

The groups were also compared in terms of inflammation score. Although score was the lowest in group 1 and the highest in group 3, there was no difference between groups $(1.54 \pm$ 0.68 vs. $2.00 \pm 0.85$ vs. $2.18 \pm 0.87 ; \mathrm{p}=0.186$ ) (Table 2).

\section{Staining by the collagen types}

Type I collagen staining was significantly different between three groups $(\mathrm{p}=0.011)$, and the post-hoc test revealed that group 1 had a significantly higher type I collagen level than those of group $3(2.18 \pm 0.75$ vs. $1.25 \pm 0.45 ; \mathrm{p}$ $=0.006$ ). However, no difference was detected between group 1 and group 2 as well as group 2 and group 3 in this regard $(\mathrm{p}=0.300$ and $\mathrm{p}=$ 0.079; respectively) (Figure 4A).

In the comparison performed in terms of type III collagen staining, a statistical difference was found between groups ( $\mathrm{p}=$ 0.002). The post-hoc test revealed that the level of type III collagen in group 1 was significantly higher than in group $3(2.27 \pm 0.78$ vs. $1.16 \pm$ $0.38 ; p=0.002$ ) and group 2 had higher level of collagen than group $3(1.90 \pm 0.70$ vs. $1.16 \pm$ $0.38 ; \mathrm{p}=0.015$ ) (Figure 4B).

\section{DISCUSSION}

Wound healing is a dynamic and complex process that started at the moment of injury; lasts for months and even years $(4,13)$. There are several parameters affecting the healing process positively or negatively in the period passed from the occurrence of a wound to the completion of tissue repair. The main target is to affect the factors playing roles in wound healing and to provide wound healing enhancement. For this, many topical and systemic agents were used and have still been used experimentally, studies are also being performed $(6,10,14,15)$. This study aimed to evaluate the effects of intraperitoneal simvastatin administration on collagen deposition, inflammation level and wound tension in an experimental wound healing model.

Besides their anti-lipid effects, statins beneficial therapeutic actions have been attributed to their non-lipid modifying ability and called pleiotropic effects such as enhancing the stability of atherosclerotic plaques, improving endothelial function, reduction of inflammation and oxidative stress, and inhibiting the thrombogenic response (7-11). Recent studies in in vivo experimental models have also shown that statins had a proangiogenic effect at low therapeutic concentrations, but the high concentration of statins induced cell apoptosis and inversely inhibited angiogenesis (16).

Previously, several experimental studies have been designed for the treatment of the delayed diabetic wound, intestinal anastomotic wound, or infected wound healing; and many statin agents have been used to assess their effects on the different phases of the healing process. Rego et al. (17) investigated the effect of topical treatment with simvastatin microemulsion on the healing of infected skin wounds in rats. In comparison with saline solution therapy, topical simvastatin administration showed a statistically significant improvement of wound healing based on bacteriological and histopathological examinations as well as the measurement of TNF- $\alpha$ and IL-1 $\beta$. Simvastatin also found to decrease leukocyte infiltration and to inhibit leucocyte-endothelial cell interactions, which confirms the protective effect against inflammatory processes. According to our data, as simvastatin doses increased, inflammatory cells decreased. However, no statistically significant differences were found between the groups regarding inflammation scores in wound areas. In another study, Sukpat et al. (9) investigated the effects of pre-treatment with low-dose simvastatin on angiogenesis and wound healing in a diabetic rat model. The rats were divided into three different groups, including control, diabetic, and diabetic pretreated with daily oral simvastatin $(0.25 \mathrm{mg} / \mathrm{kg})$. They showed that 7-day application of low-dose simvastatin before wound induction could 
increase angiogenesis and vascular endothelial growth factor (VEGF) production, reduce inflammation, and improve wound healing in diabetic rats. In another wound healing model, Karadeniz Cakmak et al. (18) evaluated the effect of simvastatin on the healing process of colonic anastomosis and anastomotic complications in an experimental model. They demonstrated that rats gavaged daily with 10 $\mathrm{mg} / \mathrm{kg}$ simvastatin significantly enhanced the wound healing at the anastomosis site by means of increasing mechanical strength and the amount of hydroxyproline level. Another study by Derici et al. (19), the authors evaluated the effect of simvastatin on the healing process of midline laparotomy via the evaluation of hydroxyproline content, breaking strength, and inflammatory changes in the abdominal fascia. In this study, 40 adult female Wistar-Albino rats were assigned to two groups, the control group was fed standard laboratory diet and the study group received oral simvastatin $(10 \mathrm{mg} / \mathrm{kg}$ once a day) with an orogastric tube for seven consecutive days until 12 hours before surgery. They showed that oral simvastatin could be used as a supporting factor in incisional wound healing because of its effect of enhancing hydroxyproline levels, increasing tensile strength, and attenuating inflammatory changes in the abdominal fascia. It was also found that collagen deposition scores were statistically significantly higher in the study group compared to the control at postoperative day 7 and 14 . We found similar results as this study. In our study, we evaluated the collagen, a final product, instead of the matrix metallopeptidase itself that is a collagenase. The levels of type I collagen and type III collagen were significantly different between the three groups. Type I collagen level was higher in rats with high-dose simvastatin than those with the placebo group. In addition, both high-dose simvastatin group and low-dose simvastatin group had significantly higher levels of collagen type III than control group. A further experimental trial by Bitto et al. (20) assessed the effects of intraperitoneal simvastatin on overall wound healing in a diabetic wound model. This study was carried out on 150 rats in total, and 10 animals were recruited in each group (diabetic or normoglycemic, simvastatin or vehicletreated, or VEGF neutralizing antibody pretreated) in each time point (3, 6 and 12 days). They showed that wound-breaking strength was significantly higher in rats treated with simvastatin compared with placebo, both amongst nondiabetic and diabetic mice at postoperative day 12. Besides, they reported that simvastatin administration increased VEGF mRNA, protein expression, and nitric oxide products in the wound in diabetic mice.

One of the main aims of the remodeling stage is to achieve the maximum tensile strength of the wound. The tensile strength always increases gradually parallel to collagen deposition and remodeling. Collagen reaches approximately $20 \%$ of its tensile strength after 3 weeks and the rate increases to $80 \%$ by 12 th week (21). Moreover, the wound continues to undergo remodeling for up to a year as the collagen is reorganized and tensile strength improves (22). In our study, there was no significant difference in tensile strength between the groups. Interestingly, unlike other studies, the tensile strength of the wounds in the low-dose simvastatin group was higher than both the high-dose simvastatin and the control groups. Possible reasons for this result may be short follow-up periods (14 days) or a negative effect of the high-dose simvastatin on another healing process that will affect the tensile strength of the wound.

In one of the limited clinical studies regarding the use of statin in wound healing, Raposio et al. (5) investigated the efficacy of topical simvastatin in the treatment of chronic vascular cutaneous ulcers. 7 patients with 11 ulcers were randomly assigned to the study group $(0.5 \%$ simvastatin-based cream) and the control group consisted of 8 patients with 9 ulcers were treated with collagen-based medications. Although topical application of a simvastatin-based cream proved to be welltolerated, it was not found to be effective in the management of chronic vascular leg ulcers in a four-week-period. In another pilot study in patients with diabetic foot ulcer (DFU) by Johansen et al. (23), six patients treated with low-dose $(10 \mathrm{mg})$ atorvastatin orally in one group and high-dose $(80 \mathrm{mg})$ atorvastatin administered in seven patients in another group in addition to conventional treatment of ulcers for six months. High-dose treatment resulted in a reduction of the recurrence and development of new neuropathic DFUs in patients presenting with a DFU compared with treatment of patients with a low-dose of atorvastatin. Also, high-dose atorvastatin was found to be associated with a 
significant decrease in C-reactive protein compared with the low-dose atorvastatin group. In a systematic review assessing of statins in promotion of postoperative wound healing in cardiac surgical patients, it was considered that statin-group drugs would appear to have the ability to modulate some of the molecular processes involved in the normal inflammatory response and assist the shortening of the natural process of the healing by facilitating the collagen production and thus, they may increase the tensile strength of the tissue (22). In a retrospective study designed in a high-risk cardiac surgical cohort, it was found that preoperative statin therapy was associated with a considerably reduced risk of postoperative infectious complications following cardiac surgery (24).

The positive effects of statins on wound healing, angiogenesis, and collagen deposition are mostly based on experimental studies with small sample sizes and short-term follow-up. Whether these statin derivatives are efficient for enhancing wound healing in clinical practice, and whether long-term use of statins causes a delay in healing or is appropriate for prevention of wound complications, are important questions that remained to be addressed in large controlled prospective clinical studies. Besides, we expect that statins could make a beneficial adjunct to clinicians in the enhancement of wound healing through stimulating cell proliferation, accelerating collagen synthesis and increasing angiogenesis, and certainly, completion of high-quality human trials will help us to obtain more information regarding such agents for wound healing in the near future.

One limitation of this study was the usage of minimum number of animals in each group for collecting data regarding collagen deposition, inflammation level, and wound tension. Moreover, we only performed an immunohistochemical evaluation of the collagen levels and inflammation score of the wound was assessed using semiquantitative scores. Therefore, future studies employing biochemical assay or gene expression are needed to determine the accurate impact of simvastatin on collagen level, angiogenesis, and VEGF production in a wound model. The longterm effects of statins or possible toxicity evaluation also needed to be addressed.

\section{CONCLUSIONS}

There has been ongoing interest on the effects of simvastatin on wound healing because of its beneficial effects on wound such as increased wound-breaking strength, faster rate of wound healing and epithelization, increased hydroxyproline content and collagen thickness, reduced neutrophil migration, and higher nitric oxide levels. Despite different results in different studies, we believe that there may be a potential role of simvastatin in the promotion of postoperative wound healing. In present study, we found that intraperitoneal simvastatin administration significantly increased type I and type III collagen levels in an experimental wound healing model; however, we did not find a positive effect of simvastatin on tensile strength and inflammation score. Therefore, more future studies which will examine the effects of statin group drugs on the wound healing are necessary for clarifying the paradoxical results.

\section{Conflict of interest: None.}

\section{REFERENCES}

1. Childs DR, Murthy AS. Overview of wound healing and management. Surg Clin North Am 2017;97:189207.

2. Broughton G 2nd, Janis JE, Attinger CE. The basic science of wound healing. Plast Reconst Surg 2006;117:12s-34s.

3. Farsaei S, Khalili H, Farboud ES. Potential role of statins on wound healing: review of the literature. Int Wound J 2012;9:238-247.

4. Velnar T, Bailey T, Smrkolj V. The wound healing process: an overview of the cellular and molecular mechanisms. J Int Med Res 2009;37:1528-1542.

5. Raposio E, Libondi G, Bertozzi N, Grignaffini E, Grieco MP. Effects of topic simvastatin for the treatment of chronic vascular cutaneous ulcers: a pilot study. J Am Coll Clin Wound Spec 2016;7:13-18.

6. Guo S, DiPietro L. Factors affecting wound healing. J Dent Res 2010;89:219-229.

7. Ko JH, Kim PS, Zhao Y, Hong SJ, Mustoe TA. HMGCoA reductase inhibitors (statins) reduce hypertrophic scar formation in a rabbit ear wounding model. Plast Reconstr Surg 2012;129:252-261.

8. Suzuki-Banhesse VF, Azevedo FF, Araujo EP, et al. Effect of atorvastatin on wound healing in rats. Biol Res Nurs 2015;17:159-168.

9. Sukpat S, Israsena N, Patumraj S. Pleiotropic effects of simvastatin on wound healing in diabetic mice. $\mathrm{J}$ Med Assoc Thai 2016;99:213-219.

10. Toker S, Gulcan E, Cayci MK, Olgun EG, Erbilen E, Ozay Y. Topical atorvastatin in the treatment of diabetic wounds. Am J Med Sci 2009;338:201-204. 
11. Ferri N, Colombo G, Ferrandi C, Raines EW, Levkau B, Corsini A. Simvastatin reduces MMP1 expression in human smooth muscle cells cultured on polymerized collagen by inhibiting Rac1 activation. Arterioscler Thromb Vasc Biol 2007;27:1043-1049.

12. Abramov Y, Golden B, Sullivan M, et al. Histologic characterization of vaginal vs. abdominal surgical wound healing in a rabbit model. Wound Repair Regen 2007; 15:80-86.

13. Leong M, Murphy KD, Phillips LG. Wound healing. In: Townsend C, Beauchamp RD, Evers BM, Mattox K, eds. Sabiston Textbook of Surgery (20th ed). Philadelphia; Elsevier; 2017: 130-162.

14. Tredget EE, Wang R, Shen Q, Scott PG, Ghahary A. Transforming growth factor-beta mRNA and protein in hypertrophic scar tissues and fibroblasts: antagonism by IFN-alpha and IFN-gamma in vitro and in vivo. J Interferon Cytokine Res 2000;20:143-151.

15. Buckmire MA, Parquet G, Greenway S, Rolandelli RH. Temporal expression of TGF-beta1, EGF, and PDGF-BB in a model of colonic wound healing. J Surg Res 1998;80:52-57.

16. Weis M, Heeschen C, Glassford AJ, Cooke JP. Statins have biphasic effects on angiogenesis. Circulation 2002;105:739-745.

17. Rego AC, Araújo Filho I, Damasceno BP, et al. Simvastatin improves the healing of infected skin wounds of rats. Acta Cir Bras 2007;22 Suppl 1:57-63.
18. Karadeniz Cakmak G, Irkorucu O, Ucan BH, et al. Simvastatin improves wound strength after intestinal anastomosis in the rat. J Gastrointest Surg 2009;13:1707-1716.

19. Derici H, Yaman I, Kara C, Kamer E, Diniz G, Ortac R. Simvastatin improves incisional wound healing in a rat model: an experimental study. Wounds 2012;24:195-200.

20. Bitto A, Minutoli L, Altavilla D, et al. Simvastatin enhances VEGF production and ameliorates impaired wound healing in experimental diabetes. Pharmacol Res 2008;57:159-169.

21. Morton LM, Phillips TJ. Wound healing and treating wounds: Differential diagnosis and evaluation of chronic wounds. J Am Acad Dermatol 2016;74:589606.

22. Fitzmaurice GJ, McWilliams B, Nölke L, Redmond JM, McGuinness JG, O'Donnell ME. Do statins have a role in the promotion of postoperative wound healing in cardiac surgical patients? Ann Thorac Surg 2014;98:756-764.

23. Johansen OE, Birkeland KI, Jørgensen AP, et al. Diabetic foot ulcer burden may be modified by highdose atorvastatin: A 6-month randomized controlled pilot trial. J Diabetes 2009;1:182-187.

24. Hartholt NL, Rettig TC, Schijffelen M, Morshuis WJ, van de Garde EM, Noordzij PG. Preoperative statin therapy and infectios complications in cardiac surgery. Neth Heart J 2014; 22:503-509.

Table 1: Inflammatory cell characteristics and scoring.

\begin{tabular}{ll}
\hline Score & Characteristics of inflammatory cells \\
\hline 0 & None \\
1 & Giant cells, plasma cells and lymphocytes \\
2 & Giant cells, plasma cells, eosinophil, and neutrophils \\
3 & Numerous inflammatory cells and micro-abscess formation \\
\hline
\end{tabular}

Table 2: Comparison of rats in terms of tissue tensile strengths, type I collagen levels, and type III collagen levels.

\begin{tabular}{lcccccc}
\hline & $\begin{array}{c}\text { Group 1 } \\
(\mathbf{n = 1 1})\end{array}$ & $\begin{array}{c}\text { Group 2 } \\
(\mathbf{n = 1 2})\end{array}$ & $\begin{array}{c}\text { Group 3 } \\
(\mathbf{n = 1 1})\end{array}$ & $\mathbf{p}^{\mathbf{1}}$ & $\mathbf{p}^{\mathbf{2}}$ & $\mathbf{p}^{\mathbf{3}}$ \\
\hline Tensile strength (N) & $8.15 \pm 3.14$ & $10.59 \pm 1.87$ & $9.47 \pm 1.32$ & 0.032 & 0.217 & 0.134 \\
Type I collagen level (0-3) & $2.18 \pm 0.75$ & $1.81 \pm 0.75$ & $1.25 \pm 0.45$ & 0.300 & $\mathbf{0 . 0 0 6}$ & 0.079 \\
Type III collagen level (0-3) & $2.27 \pm 0.78$ & $1.90 \pm 0.70$ & $1.16 \pm 0.38$ & 0.300 & $\mathbf{0 . 0 0 2}$ & $\mathbf{0 . 0 1 5}$ \\
$\begin{array}{l}\text { Score of inflammatory cell } \\
\text { infiltration (0-3) }\end{array}$ & $1.54 \pm 0.68$ & $2.00 \pm 0.85$ & $2.18 \pm 0.87$ & 0.235 & 0.101 & 0.651 \\
\hline
\end{tabular}

$\mathrm{p}^{1}, \mathrm{p}$ value of parameters obtained when compared between group 1 and group 2 .

$\mathrm{p}^{2}, \mathrm{p}$ value of parameters obtained when compared between group 1 and group 3.

$\mathrm{p}^{3}, \mathrm{p}$ value of parameters obtained when compared between group 2 and group 3. 

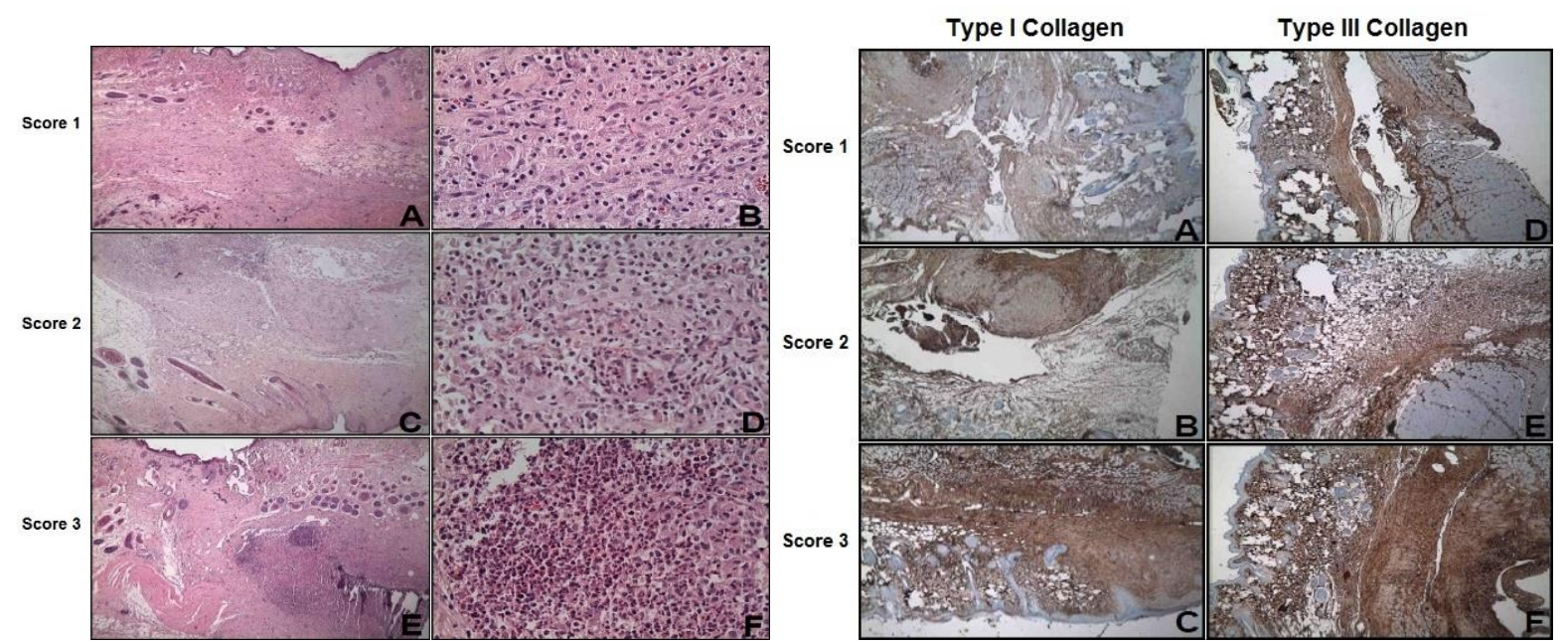

Figure 1: A tissue sample used for collagen types and scoring. A and B are the samples whose inflammation score is 1 (H\&E; $x 400$ and $\mathrm{x} 4000) ; \mathrm{C}$ and $\mathrm{D}$ are the samples whose inflammation score is 2 (H\&E; $\mathrm{x} 400$ and $\mathrm{x} 4000)$; $\mathrm{E}$ and $\mathrm{F}$ are the samples whose inflammation score is 3 (H\&E; $\mathrm{x} 400$ and $\mathrm{x} 4000$ ). Figure 2: A tissue sample used for collagen types and scoring. A, B and C are the samples whose Type I collagen scores are 1, 2 and 3, respectively (x400); D, E and F are the samples whose Type III collagen scores are 1, 2 and 3, respectively (x400).

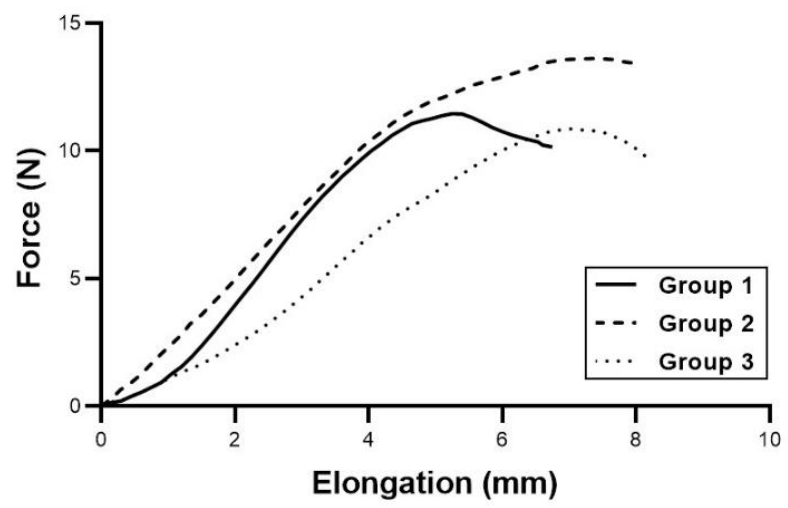

Figure 3: Elongation curves of tissues corresponding to tensile strength applied on groups according to mechanical tensile test graphics.

A

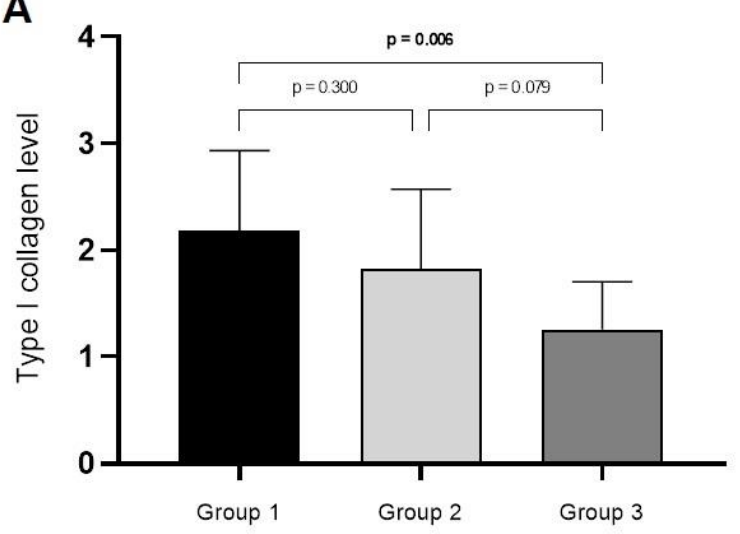

B

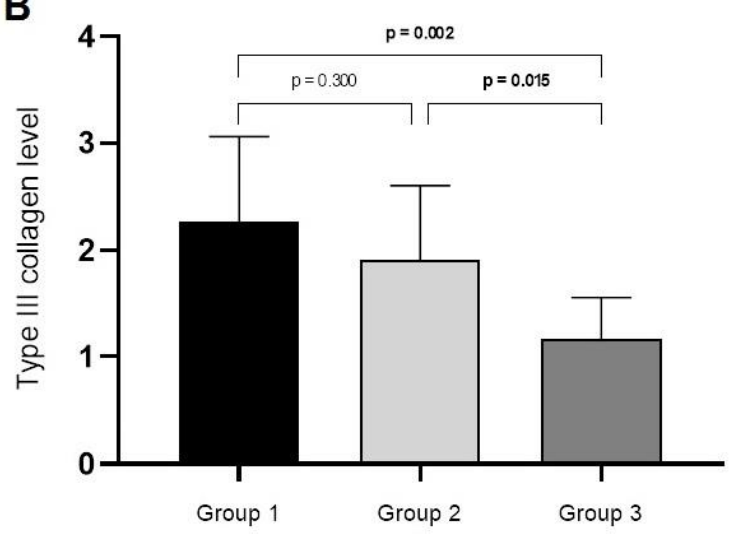

Figure 4: Collagen levels in wounds after intraperitoneal simvastatin administration. Histogram shows that group 1 (high-dose simvastatin) had significantly higher type I collagen level than group 3 (placebo) (A). The type III collagen level in group 1 (high-dose simvastatin) and group 2 (low-dose simvastatin) were significantly higher than that in group 3 (placebo) (B) 